\title{
Moral Concepts of Modern Business Processes
}

\author{
Irina Lyskova \\ Management department \\ Komi Republican Academy of State Service and Administration \\ Syktyvkar, Russia
}

\begin{abstract}
The article is devoted to the main ethical problems of modern organizations. It suggests the characteristic features of conceptual basis of forming ethical culture of business processes, and it emphasizes the significance of personal ethical culture in the aspect of business ethics, organizational behavior, and corporate culture improvement in modern socio-economic processes. The modern economic situation requires new approaches to business development, to improving the socio-cultural, socioeconomic and socio-psychological basis of self-management, cognitive and creative management.
\end{abstract}

Keywords-modern organization; business-processes; human resources management; organizational culture; morality; ethical culture; business ethics

\section{INTRODUCTION}

Characterizing modern socio-economical and sociocultural tendencies in the development of Russian society, we cannot ignore special features of social consciousness, national mentality, problems and tasks in forming efficient model of human resources culture.

It is common that success in various business processes is defined by a range of factors and conditions. In modern Russia, it takes quite a time to understand the exceptional importance of human factor, and this goes very slowly. It is likely to be so because of the historical roots of the problem, as there used to be no need to improve the motivation system and labor incentives in the sphere of material and nonmaterial production [14-18, 20]. Nevertheless, we are gradually coming to understanding of the importance of both quality management and management of quality [1, 9, 19], especially when we speak about moral principles formation in economics and moral business process culture formation in a modern organization. The efficiency of quality management depends greatly on the position, professional and individual characteristics and abilities of a manager of an organization. Nowadays a certain moral make-up is demanded from a manager as well as from any member of an organization $[7,8]$.

\section{THE MAIN CHARACTERISTIC FEATURES OF MORAL CONCEPTS AND ETHICAL CULTURE IN THE ASPECT OF MODERN BUSINESS-PROCESSES}

\section{A. The Essence of Organizational Behavior and Organizational Culture}

There is a need in modern economics to think over new moral guidelines and new approaches that may be used by highly moral, motivated, innovative and creative people who are determined to achieve great results in their labor activity. Specific features of current organizational culture model and public and individual moral culture as well, define the behavior of a man within an organization. New political and socio-economic realities change people's attitude towards the essence of labor processes and understanding the role of organizational behavior and organizational culture in marketoriented economy [2-6]. The instability of market economy dictates the necessity to transform organizations into more flexible and adaptive systems that provide for the acknowledgment of human resources priority role in industrial process. Thus, organizational culture is to play a large part in this transformation.

Organizational culture is defined as a complex notion that includes totality of values, assumptions, norms, rules, and patterns of behavior, which are accepted and shared by the biggest part of the staff. Organizational culture is viewed as a powerful strategic factor supporting personnel orientation toward solidarity and unity to perform common tasks effectively, to reach set goals. It stimulates the mobilization of people's energy and initiative and forms an efficient communication system within an organization. Frequently, they associate organizational culture with collective world outlook and treat it as one of the forms of public consciousness, stated locally as certain ideology, philosophy of an organization. It sets up some basic principles and assumptions, system of norms and values and is realized in various day-to-day activities and practice and in communication system as well.

Despite spreading the acknowledgment of its importance in modern organizational processes, there is still no standard way to characterize the concept of organizational (corporate) culture. As a rule, they stick to Edgar H. Schein's definition who is one of the leading specialists in organizational culture study. He emphasized that organizational culture includes the pattern of basic collective assumptions, acquired by a group (organization) in solving the problems of adaptation to the 
changes in the outer and through integration, which provides the effectiveness of organizational activity. Accordingly, effective patterns of professional behavior are thought generally recognized and set in the system of collective values, norms, rules of collective interaction and are passed along to new members of an organization as the right system of perception.[22, p. 31-32].

\section{B. The Main Approaches to the Characteristic of Organizational Culture}

The people in any organization are one of the main inner factors and implementations of organizational strategy, mission, philosophy and quality orientation. Realization of aims, tasks, introduction of new technologies is the result of both individual and team work.

The process of forming organizational culture in the aspect of HR-management implies the following approaches, which provide generation and development of cognitive, creative, and personal management models:

Intra-organizational approach is characterized by mission, philosophy and aims working out. These aspects refer to socially important ones in the activity; they define prospects of an organization and check whether organizational culture is determined to satisfy the customers' needs, control the realization of personnel policy in terms of staff recruitment, assessment, training and compensation.

Cognitive approach implies orientation toward establishing necessary conditions for constant professional development, skills improvement and initiative display, toward incorporating the value of innovative approaches to personnel management.

Motivational approach has its task in generating powerful motivation system to satisfy various people's requirements in professional activity, such as needs for acknowledgment, communication, self-affirmation, self-realization, achievements, stability, creative work, etc.

Symbolic approaches realized as a complex of symbolic actions, measures, traditions and ceremonies and is reflected in some concrete events that form the history of an organization, its legends, customs and heroes.

Moral culture as an essential part of organizational culture presupposes the necessity to follow moral standards and requirements, which in its turn supports forming favorable moral and psychological climate in an organization. It is also a characteristic of business communication culture, which influences the communication on the whole, emotional and psychological mood of the staff, forming collective opinion on some important issues for an organization $[11,12]$.

What is more, it is necessary to emphasize the cognitive component in personal moral culture. Ethic knowledge provides deep understanding of key principles and norms of morality, perception of correlation between moral liberty and moral responsibility, acknowledgment and understanding of civil and professional duty, professional rights and obligations, ethical norms and requirements and following common social rules [10].

Moral culture is also established at emotional and cognitive levels of a person's interaction with society and is revealed in a complex of personal characteristics such as purposefulness, persistence, confidence, energy and activity, flexibility, etc. As for organizations, their moral culture is defined by principles, values, norms, beliefs in professional activity. Moral motivation of a purposeful activity is connected with moral and emotional personal culture, with personal abilities and readiness to perform professional duties conscientiously, responsibly and honestly, directing efforts towards organizational aims and tasks, common good and personal well-being $[13-14 ; 16]$.

Modern concepts of organizing socio-economic activity are based on the specificity of cultural traditions, moral values, outlook priorities, singularity of national culture and mentality in organizational perspective $[11-12 ; 21]$. Special attention should be paid to such important trends as cognitive, creative and personal management.

\section{Socio-philosophical basics of Organizational Culture}

Socio-philosophical basics of organizational culture include not only understanding of managerial methods and approaches, but also understanding of the role of professional culture key principles. Let us mark the main of them from the point of view of forming constructive moral business relations.

The principle of ethics demands following the norms and rules of business culture, professional ethic and etiquette in the process of performing professional duties, following common cultural values of an organization and business culture recommendations.

The principle of democratization provides the collective's rights to be privy to professional tasks solving, assists collective cooperation development.

The principle of adaptivity defines the level of individual and collective readiness to solve professional tasks according to the norms and values of an organization, requirements of official behavior in changing internal and external environment within organization.

The principle of responsibilities characterized by a feeling of professional duty, diligent attitude towards accomplishing professional responsibilities.

The principle of social responsibility is based on the conscientious attitude of an organization to social tasks, supports organizational mission realization, foregrounds social, political, legal and other objectives both to the staff and to the society overall.

The principle of business partnership presupposes the high level of general and professional cultural competences, which provide personal and organizational efficiency.

The principle of social partnership promotes cooperation and mutual benefits of all the participants of processes in an organization (the staff, managers, customers, clients, etc. 
with the intermediary role of governmental institutions that provide legal, regulating, controlling functions).

The principle of paternalism provides managers' parental care about the improvement of conditions, well-being, and quality of labor activity of the collective, about forming the effective culture model and business relations model of an organization.

The principle of social justice presupposes an objective grounding of the requirements, norms and rules of official behavior, upright payment for the activity and fair distribution of goods and benefits, justice of sanctions for labor discipline breaches.

The principle of non-discrimination is characterized by constructive business relations in the sphere of professional activity, does not admit any cases of discrimination and subjective approaches for the reasons of age, gender and nationality, political and religious assumptions, etc.

The principle of effectiveness helps to provide the effectiveness of management in socio-economic, sociocultural and socio-philosophic processes in an organization, which are based on rational approaches to human resources management.

The principle of discipline makes people follow the norms, values and inner rules of an organization, makes them be responsible and dutiful.

The principle of immediacy is characterized by presence of the system of well-timed response to the circumstances and labor conditions in the team, making effective forehanded managerial decisions in analyzing and improving HR-management processes; and developing the mechanisms of organizational changes management.

The principle of loyalty reasons the acceptance of actual and long-range tasks in organizational development by the greatest part of the team, understanding of the managers' stance and acknowledging the essential role of the personnel in achieving managerial goals and solving organizational tasks.

The principle of humanism implies orientation towards creating and developing well-wishing relations and productive cooperation in an organization; it establishes sociocultural basis of business interaction,

The principle of communication presupposes the collective's readiness to form the culture of horizontal and hierarchic communication as means of efficient task solving in professional activity.

The principle of politeness defines the importance of official behavior within a team; mutual respect is considered one of the major rules in business communication.

The principle of honesty allows for diligent attitude to work, following general social and cultural norms and rules of morality, trust in people.

The principle of corporative activities understood as the harmony of interests of all the categories of the staff, which leads to the achievement of the set goals.
The principle of conservatism encourages stability, reliability and depth of business relations, provides the necessity to respect and keep the traditions of an organization in the process of creating business relations.

The principle of attraction in behavior and appearance of a business man serves the orienting point to accept the role of psychophysiological and socio-psychological factors that ensure the favorable atmosphere in an organization and to understand the importance of mutual respect among the collective; encourages constructive business communication.

The principle of self-development emphasizes the significance of constant self-improvement in professional communication and business relations that increases both personal and collective effectiveness.

\section{The Modern Problems of Forming Ethical Culture of Organization}

Moral motivation, adequate outward assessment and selfesteem in a worker's professional activity foreground the importance of personal management in various business processes such as self-organization and individual planning, self-motivation and self-control, behavioral self-analysis, taking responsibility for the process and result of making decisions and choices and for the consequences of either actions or inactions in certain situations and under certain circumstances.

We have to admit that there are some serious problems in human resources management in modern organizations in Russia. These problems are determined by the drawbacks in the system of organizational behavior and organizational culture. As a rule, they are observed in behavioral patterns of labor activity imitation, low working efficiency, idleness, lack of desire to show initiative and emotional or professional burnout. The major reason for such problems to appear is the motivational crisis in labor activity [20].

Meanwhile, it is necessary to mention that, in the professional sphere, modern people realize the great range of their wants and demands. Among the include day-to-day physiological needs, gratification that keeps a worker and his family's life and health maintained, provide stability, reliability, independence, freedom and financial security. It is possible to single out the complex of socially important demands, which form the basis of adequate motivational system in professional activity and the continuous personal development. They are: demands for communication, acknowledgment and recognition, cooperation, social status, prestige and power, self-affirmation, self-realization, competition, achievements, creation, new issues in work, getting pleasure from both processes and results, being a part of a team, etc.

The system of needs provides the grounds for forming and developing the modern staff's system of values. The values define the process of satisfying individual and collective demands.

Undoubtedly, under the influence of strong political, socio-economic and socio-cultural factors, the system of values has sustained significant changes, which is inevitably 
reflected on organizations and working process effectiveness. Still, we can name the essential features, which form basic assumptions about a person's life implication orienting points, regardless the outer factors. Family, health, education, work, career, money, communication, social activity, interests, etc. in different respect may refer to such values. Each person is to make priorities himself.

The system of needs and values of a person is transformed into targeting the individual and collective levels, thus it defines the structure and the content of professional activity.

It is especially important to single out the main types of personal aims, as they define organizing individual and collective labor activity. They are:

- Aims of production, connected with effective and high-quality performance of worker's official duties;

- Personal aims, linked with individual needs for professional development and self-realization in the sphere of professional activity.

- Aims of status uniting power, authority, prestige, selfaffirmation and recognition within a team;

- Social aims produced by social activity of people, needs for participation, empathy, communication, social support, etc.

- Aims of optimization, which depend on the needs, objective and subjective circumstances and conditions.

\section{E. Professional Norms and Values of Modern Organization}

The value-normative aspect of the activity in modern organizations is characterized by a range of norms and rules that define the realization of the official behavioral model and by priorities and values of business communication culture. The normative activity is connected with all the organizational subsystems such as management, legal and socio-psychological subsystems, subsystem of formal and informal communication. Not infrequently, the norms acquire the status of common requirements that people have to follow.

A complex of professional norms regulates organizational behavior. These norms judged by their meaning may be classified into prohibitions, frames and patterns.

Prohibitions imply certain restrictions in motives of people's behavior, taking personal responsibility for the choice and making decisions. Personal consciousness of prohibitions motivates people to perform their professional duties honestly and diligently, allowing them to understand the essence of personal moral freedom and moral responsibilities. Moral restrictions in the sphere of professional activity may be defined not only by cultural requirements but also by legal ones.

Normative frames get the meaning of prescriptions and edifications, which condition the specifics of official behavior in certain sphere of professional activity. This normative category is to regulate organizational behavior.

Normative patterns establish positive models of behavior in individual and collective consciousness that are advisable from the point of view of an organization, provide the efficiency of its activity, form the standards and requirements that are understood and accepted dew to personal culture and personal mechanisms of behavior regulation.

Following official norms depends on the importance of social opinion as a form of social control and conscience works as inner regulator of a person's behavior. In modern conditions in all the spheres of social life they emphasize the role of morality, moral reliability and personal moral responsibility, especially in professional activity.

The system of professional norms in any organization is based on the system of organizational values. Among the basic and common values in business relations we may mention the following ones:

- Professional competence and the culture of business communication that provide authority, credit, stability and positive business relations. This characteristic promotes forming high professional culture of a person, which means open interrelation, reliability, solidarity, sociability and readiness to perform professional tasks.

- Professional duty that encourages powerful motivational system in personal and collective activity.This system stimulates the desire to work hard, diligently and responsibly for the common wealth. Understanding the essence of professional duty is inevitably linked to the matter of professional activity and its social set.

- Moral responsibility for both the process and the result of work, which is voluntarily and knowingly accepted by the staff of an organization according to work functions and moral assumptions. It defines people's abilities to use their professional freedom adequately, to follow common moral requirements, to make morally right choices and to understand the consequences of the decisions made.

- Professional honor is a moral, emotional and volitional category, which stresses the specifics and social importance of a people's professional activity, their social status, personal image and prestige.

- Professional dignity as a moral value draws attention to the idea of equality of all the staff members regardless their status and proves social importance of all the aspects of professional activity that provide life and well-being of an organization. Professional dignity is a part of human dignity, which is a feeling of one's social importance, value and self-affirmation, no matter what the circumstances are like.

- Professional conscience is a special moral, emotional and psychological mechanism that provides self- 
control and self-regulation in professional behavior according to work functions, duties and responsibilities. The significance of this inner mechanism of personal behavior regulation increases when there is no outer control. The presence of professional conscience enhances self-motivation, self-organization and self-control in the process of labor activity.

As we see, professional characteristics of a person and his moral culture are based on the system of needs, complex of personal and collective values, aims and norms. They form moral and professional culture of people, provide the high level of readiness for self-realization and continuous development in professional sphere, understanding of professional duty, responsibility, honor and conscience.

\section{CONCLUSION}

Thus, personal moral culture should be acknowledged as the basis of forming moral economy and moral culture of business processes in an organization. It is necessary to notice that the subject of economics as a science and the economic system itself was, at first, inseparable from moral aspects of production, distribution and consumption of social goods. As for Russian economic philosophy, the idea of social equality and the mechanisms of its realization embodied the ideal of moral economy.

Accordingly, there is a great number of economical, psychological and emotional aspects that serve to support the development of Russian economy. They include deep understanding of key concepts of forming moral culture in modern business processes, emphasizing the tasks of personal moral culture development, and recognition of human resources' role in organizational activity. Of the importance of modern principles in moral economy, acknowledgment of the necessity to improve the system of motivation, targeting, effective labor processes organization and many others is deeply understood, as well. All these may work and contribute into organizational well-being in the situations of incertitude, unpredictability and high international economic risks and may raise the level of labor organization and effectiveness in Russia.

\section{REFERENCES}

[1] Assen, M. Van, Berg G. Van den, Pietersma, P., (2013). Key management models. The 60+ models every manager needs to know. FT. Prentice Hall. 2nd edition. 3d ed. Moscow: BINOM. Laboratoriya znaniy. - 319 p. ISNB 978-5-9963-1665-6.

[2] Blinov, A.O. (2014). Moral economy and liberalism of Russia. The Russian Academic Journal No. 1 (27). 26-29.

[3] Blinov, A.O. (2014). The moral problem of poverty in the Russian economy. The world of new economy. No. 1. 35-41.

[4] Blinov, A. O. (2012). The role of the state in organizing cognitive management. Universities for Tourism and Service Association Bulletin. No. 1. 87-94

[5] Blinov, A. O., Rudakova O.S. (2013). Reengineering of human resources as a way of organizations. Economy and management: problems and decision]. No. 4 (16). 62-69.

[6] Blinov, A. O., Ugryumova N.V. (2015). Features of the decisionmaking process and diagnostics of the problems of change management in modern organizations. Economics: Yesterday, Today and Tomorrow. No. 1-2. 58-68.

[7] Covey S.R. (2015). The 7 habits of highly effective people. Restoring the character ethics. 10 ed. Moscow: Al'pina Pablisher. 396 p. ISNB 978-5-9614-5042-2.

[8] Covey S.R. (2014). The $8^{\text {th }}$ habit. From effectiveness to greatness. 9 ed. Moscow: Al'pina Pablisher. 408 p. ISNB 978-5-9614-4719-4.

[9] Imai, M. (2015). Kaizen. The key to Japan's competitive success. Mc Graw-Hill Publishing Company. 8 ed. Moscow: Al'pina Pablisher. 274 p. ISNB 978-5-9614-5387-4.

[10] Lyskova, I.E. (2015). Moral responsibility and moral freedom in the aspect of self-management. Economics and management: analysis of tendencies and perspective of development. Anthology of the XX International scientific-practical Conference, Novosibirsk: TSRNS, pp. 13-17. ISNB 978-5-00068-302-6.

[11] Lyskova, I.E. (2015). Ethical culture of personality in the aspect of business ethics. Problems of economics and management. No. 11 (51). 11-15. ISSN 2223-5313.

[12] Lyskova, I.E. (2016). The main tasks of business communications development in modern organization. [Problems of economics and management]. No. 1 (53). 4-9. ISSN 2223-5313.

[13] Lyskova, I.E. (2014). The philosophic and sociological roots of selfmanagement. In the World of Scientific Discoveries. Human and Social Sciences.. Krasnoyarsk: Publishing House Science and innovation Center, 2014. No. 7.2 (55). 757-776.

[14] Lyskova, I.E. (2015). Socio-psychological basis of self-management (historical aspect). Law, Economy and management in Modern Ambience. $4^{\text {th }}$ International Conference. 17-19 April 2015, Belgrad, Serbia. pp. 251-260.

[15] Lyskova, I.E. (2015). The first experience of the University Extension Movement in Russia (to the question of the history of selfmanagement). In: From the Other Shore: London Journals in Economics, Marketing, Finance, Business and Innovation. A collection of Scientific Papers. London. pp. 144-148. URL: http://archiv.gpscience.org/wp-content/uploads/2015/05/0315In 144148.

[16] Lyskova, I.E. (2015). Psychological aspect of self-management. Economic psychology: modern problems and perspective of development. Anthology of the XV International scientific-practical Conference. Sant-Petersburg. 188-194.

[17] Lyskova, I.E. (2016). Idea of progress in the aspect of selfmanagement. Modern management: problems and perspectives. Collection of articles. P. 1. Sant-Petersburg.66-70. ISBN 978-5-73103446-3.

[18] Lyskova, I.E. (2014). The Sources of Self-Management in Russia // The Second International Conference on Economic Sciences. Proceedings of the Conference (June 16, 2014). "East West" Association for Advanced Studies and Higher Education $\mathrm{GmbH}$. Vienna. pp. 40-46.

[19] Marr, B. (2014). Key performance indicators. The 75 measures every manager needs to know. PEARSON. Moscow: BINOM. Laboratoriya znaniy. - 340 p. ISNB 978-5-9963-1635-9.

[20] Robbins L. (2013) A history of economic thought. The LSE Lectures. PRINCETON UNIVERSITY PRESS (1998)]. Moscow. - 496 p. ISBN 978-5-93255-365-7.

[21] Csikszentmihalyi, M. (2015). Flow. The psychology of optimal experience. Moscow: Smysl, Al'pina non-fikshn. - 461 p. ISBN 9785-91671-364-0

[22] Schein, E.H. (2002). Organizational culture and leadership. SantPetersburg: PITER. - 336 p. ISBN 5-318-00573-X. 